\title{
HIV/AIDS Knowledge, Attitudes and Behaviors Assessment of Chinese Students: A Questionnaire Study
}

\author{
Xiaodong Tan*, Jingju Pan, Dong Zhou, Chunhong Wang, and Chaojun Xie \\ School of Public Health, Wuhan University, Donghu Road 115, Wuhan 430071, P.R. of China \\ *Correspondence to Dr. Xiaodong Tan; E-mail: xiaodongtan@yahoo.com \\ Received: 12 August 2007 / Accepted: 16 September 2007/ Published: 30 September 2007
}

\begin{abstract}
The objective of this study was to assess students' knowledge, attitudes and practices on HIV and AIDS. A questionnaire was administered to a cross section of 259 Chinese undergraduates. Respondents were asked to provide information about knowledge and attitudes about HIV/AIDS. Study results indicated that the majority of undergraduates had a moderate level of HIV and AIDS knowledge, acceptance and attitudes towards people with HIV and AIDS. Boys had more acceptance and positive attitudes towards people with HIV and AIDS than girls. Students majoring in medicine performed better (more knowledgeable and accepting) than non-medical students. Differences between students with various monthly expenditures were found-- $6.2 \%$ of students had $3-5$ sexual partners which has rarely been found in Chinese students; most students did not know HIV VCT centers and most students did not show their confidence for controlling of HIV and AIDS in China. In conclusion, students' knowledge about HIV/AIDS was uneven. A peer educational program to talk about self esteem, healthy sexual attitudes, being human-accepting and loving should be developed in the near future.
\end{abstract}

Keywords: HIV/AIDS, undergraduates, knowledge, attitude, practice

\section{Introduction}

Since the first case of HIV was recognized in the United States in 1981, HIV has spread rapidly throughout the world. Statistics from the Joint United Nations Programme on HIV/AIDS (UNAIDS) and the World Health Organization (WHO) in 2006 show that the number of people living with HIV at the end of 2005 totaled 38.6 million (33.4-46.0 million). An estimated 4.1 million [3.4 million-6.2 million] were newly infected with HIV and an estimated 2.8 million [2.4 million-3.3 million] lost their lives to AIDS. Although the latest UNAIDS and WHO estimates are lower than those published in the AIDS epidemic update-December 2005, the number of people living with HIV has continued to rise [1].

China is one of the countries experiencing a sharp increase in the number of HIV infections. China ranks 13th globally and second in Asia [2] with the number of people living with HIV estimated to be 650,000 $(540,000-760,000)$ at the end of 2005 according to China Ministry of Health and UN Theme Group on HIV/AIDS.
In 2005, there were an estimated 70,000 new HIV infections (range: 60,000 to 80,000), and there were an estimated 25,000 AIDS deaths (range: 20,000 to 30,000). There are signs that HIV is spreading beyond populations with high risk behavior and into the wider population in parts of China; there is a potential risk that the epidemic will spread further [3].

Young people are particularly vulnerable to the HIV pandemic. Over half of all new infections worldwide are among young people between the ages of 15 and 24 . Every day, 6,000 young people become infected with HIV - more than five every minute [4]. In the United States alone, half of all new infections are estimated to be among people under age 25 years and the majority of young people are infected sexually [5]. Anonymous testing among unmarried young people carried out in China found HIV prevalence of $1 \%$ [6]. Both sexually active and promiscuous young people in China, especially university students, are more likely to be among the affected target population, because in recent years they have developed more casual attitudes towards premarital 
sex, due to the rapid development of the economy, the influence of mass media on the perception of sex, and the degradation of traditional value, in addition to being sexually mature much earlier than before. If these individuals lack adequate information regarding HIV knowledge and behavior, they might be hit hard by the HIV pandemic. Therefore, it is essential to assess the knowledge, attitudes and practices of students regarding HIV and AIDS before planning appropriate preventive measures. The aims of the study were to assess students' knowledge, attitudes and practices regarding HIV and AIDS and to identify differences in HIV knowledge, attitudes, and practices by gender, major, and monthly expenditure.

\section{Material and Methods}

\section{Sampling}

Stratified cluster sampling was carried out to select 259 university students from different faculties (including Humanities, Social Science, Mathematics and Statistics, Engineering, Information Management and the Faculty of Medicine) of Wuhan University who participated in the study. Students were informed about the general objectives of the research and were advised not to write their names on the questionnaire in order to ensure the confidentiality of the information provided.

\section{Questionnaire}

Questionnaire used for this study was modified according to WHO recommendation and Chinese culture custom. Before the questionnaire was used for the investigation, the validity and reliability tests were performed, and the both of them have satisfied results: validity was higher than 0.7 and reliability was 0.78 .

A self-administered questionnaire was used to investigate knowledge, attitudes, and practice regarding HIV and AIDS. The questionnaire utilized in this survey was based on the WHO AIDS program regarding knowledge, attitudes, beliefs and practices (KABP) in 1988 , as well as other related literature. The questionnaire was divided into three broad sections: (1) sociodemographic characteristics, which included gender, faculty, living arrangement, and monthly expenditure; (2) sources of information about HIV and AIDS; and (3) HIV knowledge, attitudes, and practice. Students' knowledge about HIV and AIDS with respect to sources of infection, routes of transmission, prevention and perceived risk was evaluated. We assessed the student's attitudes through the following aspects: whether they held stigma or discriminated against people living with HIV, their willingness to learn about HIV and AIDS and the supporting policies aimed at preventing HIV and so on. The use of condoms, prompt treatment of sexually transmitted infections STIs and voluntarily donating blood, etc, were evaluated in practice section.

Every student was asked to mark the correct answer for each question. On each of these questions, one or more points were awarded for each correct answer or according to the degree of response for the attitude questions. No points were awarded to an incorrect choice or having no response. The total score ranged from 0 to 57. Students with higher scores had greater HIV knowledge, more accepting attitudes about HIV, and engaged in fewer HIV risky behaviors.

\section{Data Analysis}

The statistical package for social sciences (SPSS) version 11.5 was used to enter and analyze the data. Obtained data were evaluated by frequency and percentages ratios, Chi-square $(\chi 2)$, Non-parametric tests and logistic regression analyses. Testing was done using the .05 level of significance.

\section{Results}

\section{Sample Characteristics}

259 students participated in the survey, of whom 125 $(48.6 \%)$ were male and $132(51.4 \%)$ were female; 42 (16.3\%) were majoring in Humanities, 76 (29.5\%) in Social Science, $48(18.6 \%)$ in Mathematics and Statistics, 32 $(12.4 \%)$ in Engineering, $34(13.2 \%)$ in Information Management, $26(10.1 \%)$ in Medicine. Most of the students were living on campus, except for 7 students $(2.7 \%)$, who rented apartment off campus. The monthly expenditures of 157 students (61.8\%) ranged from 300 Yuan to 599 Yuan, while the others were above 600 Yuan.

\section{Sources of HIV/AIDS Information}

As the results in figure 1 show, the sources of HIV/AIDS information were diverse. Most students reported that mass media (newspapers and magazines, $64 \%$; television and radio, $48.8 \%$ ) was the major sources of getting information about HIV and AIDS, followed by school and public health promotion $(32.9 \%$ and $22.9 \%$, respectively). Some students received their information from friends $(20.9 \%)$ or from other sources $(19.8 \%$, Internet, for instance). Information from doctors and nurses were the least chosen method among the students.

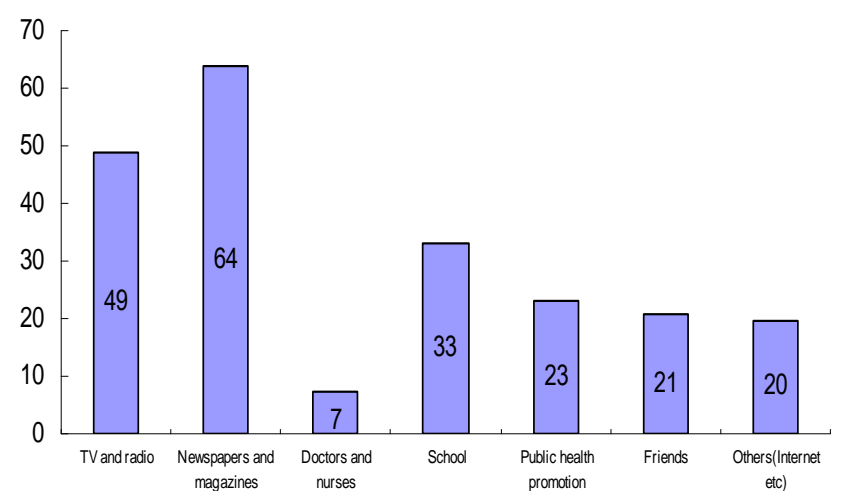

Figure 1: Distribution of HIV/AIDS Information among university students. 
Table 1: Frequency and percentages of responses of HIV/AIDS knowledge

\begin{tabular}{lcr}
\hline Questions & Frequency & $\%$ \\
\hline \multicolumn{3}{c}{ General knowledge } \\
Awareness of HIV & 258 & 100 \\
HIV is a contagious disease & 254 & 98.4 \\
Sources of HIV/AIDS infection & & \\
People living with HIV and AIDS & 251 & 97.3 \\
Relatives of people living with HIV & 25 & 9.7 \\
People having casual contact with people & 40 & 15.5 \\
living with HIV & & \\
Total correct answer about sources of & 179 & 69.4 \\
HIV infection &
\end{tabular}

\section{Knowledge of HIV/AIDS}

The analysis of data revealed that most students had a good to excellent knowledge about most items pertaining to HIV and AIDS. The total HIV knowledge score ranged from 19 to 35, with a mean of $28.06(\mathrm{SD}=2.93)$. When the sample was stratified into high (scores of 31-35) and moderate (scores below 31), the data showed that although some had high knowledge scores $(n=46,17.8 \%)$. The majority had moderate knowledge $(n=212,82.2 \%)$.

Table 1 indicates that every student in our study was aware of the existence of HIV in China. 254 (98.4\%) considered HIV a contagious disease. There was a high level of knowledge on the sources of HIV/AIDS infection. $251(97.3 \%)$ knew that sources of HIV/AIDS infection were those infected with HIV and AIDS patients, while 15.5 percent mistook people who had casual contact with AIDS as sources for HIV/AIDS infection. The total correct answer rate pertaining to sources of HIV/AIDS was $69.4 \%$.

Knowledge regarding transmission modes was fairly good -- 98.8\% pointed out that HIV was sexually transmitted. Most were also aware that HIV was transmitted by the sharing of needles by drug users $(n=252,97.8 \%)$, receiving blood from an infected person $(n=249,96.5 \%)$, and from mother-to-child transmission $(n=232,89.9 \%)$. However, only $110(42.8 \%)$ realized that HIV could be transmitted by having oral sex with an infected person. Still, there were some misconceptions regarding non-transmittable routes. $40.3 \%$ of those polled believed that HIV could be transmitted through insect bites, and $10.1 \%$ believed HIV could be transmitted by sharing public swimming pools with an infected person. In all, 122 (47.3\%) students answered all HIV transmission questions correctly.

Table 2: Frequency and percentages of responses of knowledge on AIDS policies

\begin{tabular}{|c|c|c|}
\hline Knowledge on AIDS policies & Frequency & $\%$ \\
\hline \multicolumn{3}{|c|}{ HIV/AIDS antibody testing institute } \\
\hline Know & 71 & $\overline{27.8}$ \\
\hline Have no idea & 184 & 72.2 \\
\hline \multicolumn{3}{|c|}{ Free HIV antibody testing } \\
\hline Yes & 117 & 45.9 \\
\hline No & 34 & 13.3 \\
\hline Have no idea & 104 & 40.8 \\
\hline \multicolumn{3}{|c|}{ Free treatment for AIDS patients } \\
\hline$\overline{\text { Yes }}$ & 56 & 22.0 \\
\hline No & 134 & 52.5 \\
\hline Have no idea & 65 & 25.5 \\
\hline \multicolumn{3}{|c|}{ AIDS epidemic trend in China } \\
\hline Accelerate & 221 & 87.0 \\
\hline Slow down & 6 & 2.4 \\
\hline Keep the same & 2 & 0.8 \\
\hline Have no idea & 25 & 9.8 \\
\hline
\end{tabular}

Students' knowledge in the area of prevention was moderate. More than $80 \%$ of the students gave correct responses to the majority of questions. Unexpectedly, only 
$52(20.6 \%)$ knew the ABC (Abstinence, Being faithful and Condom use) method for preventing HIV. Only 28 (10.9\%) students correctly chose all the prevention methods.

Table 2 shows that students lacked knowledge about HIV-related policies. $72.2 \%$ students had no idea about HIV VCT centers. Only $45.9 \%$ and $22 \%$ knew that HIV antibody testing and treatment for AIDS patients were free of charge in China.

\section{Attitudes and Beliefs about HIV/AIDS}

Generally, the respondents' attitudes towards people living with HIV and AIDS were found to be accepting and positive. Table 3 illustrates that nobody held discriminating attitudes towards people with HIV/AIDS $153(59.8 \%)$ voiced strong willingness to live in the same community with HIV/AIDS people. However, 23\% felt afraid to have contact with them. Most students supported the policies designed to prevent and control HIV/AIDS, but only $22.6 \%$ had confidence in the government to bring HIV under control. The lack of confidence in the government to control the HIV epidemic is very significant.

Table 3: Frequency and percentages of responses to attitudes and belief questions $(\mathrm{n}=256)$

\begin{tabular}{lcr}
\hline Questions & Frequency & $\%$ \\
\hline \multicolumn{2}{c}{ Attitudes towards HIV carriers and AIDS patients } \\
\hline $\begin{array}{l}\text { Willing to live with people } \\
\text { having HIV/AIDS in the same } \\
\text { community }\end{array}$ & 153 & 59.8 \\
$\begin{array}{l}\text { Reluctant to live with people } \\
\text { having HIV/AIDS in the same } \\
\text { community }\end{array}$ & 103 & 40.2 \\
$\begin{array}{l}\text { Dislike having contact with } \\
\text { HIV/AIDS people }\end{array}$ & 59 & 23.0 \\
$\begin{array}{l}\text { Feel empathetic towards people } \\
\text { living with HIV and AIDS }\end{array}$ & 103 & 40.2 \\
$\begin{array}{l}\text { Contact with people living with } \\
\text { HIV as before }\end{array}$ & 94 & 36.7 \\
$\begin{array}{l}\text { Discriminate against people } \\
\text { living with HIV and AIDS }\end{array}$ & 0 & 0 \\
\hline \multicolumn{1}{c}{ Attitudes towards prevention and control policies } \\
\hline $\begin{array}{l}\text { Provide condoms free in } \\
\text { entertaining places }\end{array}$ & 221 & 86.3 \\
$\begin{array}{l}\text { Support public health promotion } \\
\text { Chinese government capable of } \\
\text { controlling HIV/AIDS } \\
\text { epidemics }\end{array}$ & 254 & 98.8 \\
\hline
\end{tabular}

\section{Practices about HIV/AIDS}

It was found that 96 students $(37.2 \%)$ had boyfriends/girlfriends, and 154 students (59.7\%) admitted to having sexual fantasies. Rates of expression of having sexual intercourse and masturbation were $6.9 \%$ and $28.8 \%$ respectively. No one in our study had ever engaged in commercial sexual intercourse. Their first sexual partner was their boyfriend/girlfriend. Age at onset of sexual intercourse ranged from 18 to 23 . The rate of condom use during sexual intercourse was only $35.7 \%$, while $43.7 \%$ of participants reported condom failure during their last encounter.

Students were asked how they would respond if they had symptoms of an STI ---184 (73\%) respondents stated they would treat the STI promptly -- $213(82.9 \%)$ desired to learn more about HIV while only $176(69 \%)$ were willing to spread HIV knowledge.

\section{Gender differences}

With regard to gender differences, our findings suggested that gender was not associated with the number of correctly answered HIV knowledge and practice questions except for two questions: regarding transmission of the disease via oral transmission and prevention by using condoms correctly during sexual intercourse, where boys preformed better $(\chi 2=15.281, p=$ $0.000 ; \chi 2=4.594, p=0.032$ respectively). Nonetheless, gender differences did exist in attitudes towards people living with HIV and AIDS with boys expressing greater acceptance than girls $(z=-2.153, p=0.031)$.

\section{Differences among different faculties}

In comparing different faculties, as we anticipated, there were statistically significant differences in HIV knowledge between medical students and non-medical students, with the latter scoring less than their counterparts $\quad\left(\chi^{2}=12.912, p=0.024\right)$, especially in knowledge concerning HIV policies. In terms of attitudes, there were no significant differences in overall scores, though slight distinction in willingness to reside in the same community with people living with HIV $\left(\chi^{2}=11.300, p=0.046\right)$.It is probably because students with good knowledge about AIDS did become more tolerant of people with AIDS.

\section{Differences among different monthly expenditure}

Interestingly, there were differentiations in students with various monthly consumptions were found in our study. Results in Table 4 showed students with monthly consumption between 300-599 Yuan scored higher than those above 600 Yuan in knowledge, attitudes and pertinent practices. In general, students with monthly living expenditure between 300-599 Yuan are mostly from ordinary families in China, whereas above 600 Yuan means those students' families may be better off. Nonetheless the latter scored less than their fellow students. In health promotion thereafter, these students should be paid special attention. 
Table 4: Monthly consumptions and differences in knowledge, attitudes and practices on HIV/AIDS

\begin{tabular}{|c|c|c|c|c|c|c|}
\hline \multirow[b]{2}{*}{ Group } & \multicolumn{2}{|c|}{ Knowledge } & \multicolumn{2}{|c|}{ Attitudes } & \multicolumn{2}{|c|}{ Practices } \\
\hline & $\begin{array}{c}\text { Scores } \\
\leq 30\end{array}$ & $\begin{array}{c}\text { Scores } \\
\geq 31\end{array}$ & $\begin{array}{c}\text { Scores } \\
\leq 10\end{array}$ & $\begin{array}{c}\text { Scores } \\
\geq 11\end{array}$ & $\begin{array}{c}\text { Scores } \\
\leq 8\end{array}$ & $\begin{array}{c}\text { Scores } \\
\geq 9\end{array}$ \\
\hline $\begin{array}{l}\text { Monthly } \\
\text { consump- } \\
\text { tion } \\
<600 \text { Yuan }\end{array}$ & 112 & 45 & 120 & 37 & 20 & 137 \\
\hline $\begin{array}{l}\text { Monthly } \\
\text { consump- } \\
\text { tion } \\
>700 \text { Yuan }\end{array}$ & 96 & 1 & 89 & 8 & 55 & 42 \\
\hline $\begin{array}{l}\text { Mann- } \\
\text { whitney } \\
\text { test }\end{array}$ & $\begin{array}{l}Z=- \\
p=0\end{array}$ & $\begin{array}{l}5.545 \\
.000\end{array}$ & $\begin{array}{l}Z=- \\
p=0\end{array}$ & $\begin{array}{l}3.101 \\
.002\end{array}$ & $\begin{array}{l}Z=- \\
p=0\end{array}$ & $\begin{array}{l}7.448 \\
0.000\end{array}$ \\
\hline
\end{tabular}

Table 5: Logistic Regression Analysis of Higher knowledge score $\geq 31$ (1) vs. moderate knowledge score $\leq 30$ (0)

\begin{tabular}{|c|c|c|c|c|c|}
\hline Groups Compared & $B$ & S.E. & $p$ & OR & $95 \% C I$ \\
\hline $\begin{array}{l}\text { Humanities } \\
\text { Faculties }\end{array}$ & -0.295 & 0.642 & 0.646 & 0.744 & $\begin{array}{r}0.211- \\
2.620\end{array}$ \\
\hline $\begin{array}{l}\text { Social Science } \\
\text { Faculties }\end{array}$ & -0.659 & 0.583 & 0.258 & 0.518 & $\begin{array}{r}0.165- \\
1.622\end{array}$ \\
\hline $\begin{array}{l}\text { Mathematics and } \\
\text { Statistics Faculty }\end{array}$ & -0.350 & 0.603 & 0.562 & 0.705 & $\begin{array}{r}0.216- \\
2.299\end{array}$ \\
\hline Engineering Faculty & -0.330 & 0.797 & 0.679 & 0.719 & $\begin{array}{r}0.151- \\
3.426\end{array}$ \\
\hline $\begin{array}{l}\text { Information } \\
\text { Management } \\
\text { Faculty }\end{array}$ & -2.167 & 0.883 & 0.014 & 0.114 & $\begin{array}{r}0.020- \\
0.646\end{array}$ \\
\hline Medicine Faculty & 0 & - & - & - & - \\
\hline Gender(1) & & & & & \\
\hline Male & 0.898 & 0.545 & 0.100 & 2.454 & $\begin{array}{r}0.843- \\
7.145\end{array}$ \\
\hline Female & 0 & - & - & - & - \\
\hline \multicolumn{6}{|c|}{ Monthly consumption } \\
\hline $\begin{array}{l}\text { Monthly } \\
\text { consumption below } \\
600 \text { Yuan }\end{array}$ & 3.867 & 1.035 & 0 & 47.806 & $\begin{array}{r}6.288- \\
363.433\end{array}$ \\
\hline $\begin{array}{l}\text { Monthly } \\
\text { consumption above } \\
600 \text { Yuan }\end{array}$ & 0 & - & - & - & - \\
\hline $\begin{array}{l}\text { Boy/girlfriend now } \\
(1=\text { Yes })\end{array}$ & 0.267 & 0.408 & 0.513 & 1.306 & $\begin{array}{r}0.587- \\
2.905\end{array}$ \\
\hline $\begin{array}{l}\text { Having sex illusion } \\
(1=\text { Yes })\end{array}$ & -0.700 & 0.502 & 0.163 & 0.496 & $\begin{array}{r}0.186- \\
1.327\end{array}$ \\
\hline $\begin{array}{l}\text { Having } \\
\text { masturbation } \\
(1=\text { Yes) }\end{array}$ & -0.493 & 0.547 & 0.367 & 0.611 & $\begin{array}{r}0.209- \\
1.783\end{array}$ \\
\hline $\begin{array}{l}\text { Having intercourse } \\
(1=\text { Yes })\end{array}$ & -1.609 & 1.138 & 0.157 & 0.200 & $\begin{array}{r}0.022- \\
1.861\end{array}$ \\
\hline
\end{tabular}

In addition, we utilized the logistic regression analyses to see whether the following variables, such as: colleges, gender, monthly expenditure, having boyfriend/girlfriend, etc, had association with knowledge, attitudes and practices scores.

As Table 5 illustrated, students from Information Management Faculty got lower scores in knowledge compared with Medical students $(\mathrm{OR}=0.114, \mathrm{p}=0.014)$. Once again, students with moderate monthly expenditure were nearly 47 times more likely to get high scores in knowledge, 2.7 times to score higher on the attitude and 11.6 times higher in reported practices (not shown). The remaining variables, gender, having boyfriends/ girlfriends, having sexual fantasies, masturbation and intercourse were not significantly associated with scores in HIV/AIDS knowledge, attitudes and practice.

\section{Discussion and Conclusion}

Our study found that newspapers and magazines were the most common ways for participants to receive information about HIV. Print media is more accessible to the broader student body whereas computers are less common. As this method is widely accessible to the student body, assuring effective HIV messages for young adults should be promoted. Overall, results from our study demonstrated that the majority of university students in this study had a moderate level of HIV knowledge, and tolerant and positive attitudes towards people live with HIV/AIDS. This outcome is similar to other studies which were performed among university students in other parts of China $[7,8,9]$, but much better than studies conducted among other groups, such as hotel attendants [10], criminal suspects [11] and others [12]. The findings from this study are attributed to years of sustained public health promotion by the government. The high quality of education received by students can also play a role in students' good performance. Besides, a favorable fact which cannot be neglected is that today's students live in an era of mass information, in which they have easier access to HIV information compared with decades ago. Positive signs that we have found in our study are: age at first intercourse among our students was between 18-23 years, much older than that of USA (13 years mostly) [13]; only $6.2 \%$ had $3-5$ sex partners, whereas $16 \%$ reported in the United States [14]; 0.4\% (one student) had a history of an STI in our study compared with $9 \%$ in other studies [13]. Only $6.9 \%$ reported having sexual intercourse in our study, much lower than other countries, like $48 \%$ in the United States in 1997[14], and 19\% in its Turkish counterpart [15]. It is also lower than previous study performed in Yunnan University in China [16]. This figure may be an underestimation of sexual behavior, because data were self-reported by students plus relatively small sample size.

However, there is still room for improvement. First of all, it is the uneven knowledge in the subcategories of mode of transmission, prevention and general knowledge. As high as $40.3 \%$ students still believed mosquitoes are 
vectors of HIV and $24(9.3 \%)$ thought sharing public swimming pools with infected people were risky. These findings were consistent with those of other studies in China $[17,18,19]$. In our study, only 110 (42.8\%) knew that HIV could be transmitted through oral sex with HIV infected people. Most students had no idea about ABC Prevention method. They also lacked understanding about the relationship between STIs and increased HIV transmission.

Secondly, We found that condom use was not correlated with knowledge among university students in our study, for $93.4 \%$ were aware that condom use during sexual intercourse is an essential component of both HIV/AIDS prevention as well as prevention of other sexually transmitted disease, whereas the rate of wearing condom among students having sexual intercourse each time was $35.7 \%$, still lower than the country mentioned above which was 57\% [20]. Therefore, it will be important in future HIV prevention campaigns to focus not only on HIV knowledge but also on developing and maintaining safe sexual behavior. Last but not least, the majority of students do not have a clear understanding of HIV policies. It is probably because mass media education was not thorough enough and the coverage of such content remains low. The government should focus on ensuring adequate knowledge among health care workers, local government leaders and peoples and people living with HIV. Broader understanding of HIV policies among general community might encourage more students to seek HIV testing as they would understand the penalties for discrimination and realize that they would have access to free treatment when needed. Greater understanding about the right of peoples living with HIV would also help them somewhat gain develop greater acceptance.

In conclusion, it is quite important that university students understand HIV prevention and transmission and develop humanistic attitudes. Condoms should be promoted in universities. This is a good time to have a peer education program to address self esteem, healthy sexual attitudes, being human-accepting and loving.

\section{References}

1. UNAIDS: Global AIDS epidemic continues to grow http://www.who.int/hiv/mediacentre/news62/en/inde x.html.

2. Yi, Z; Hua, X.: Health education and intervention: an effective way of controlling AIDS epidemic. J. Med. Forum, 2004, 25(1), 1-6.

3. Chinese Ministry of Health and UNAIDS, AIDS Epidemic prevention progress in China. People's Health Press: Beijing, 2006, pp 16-21.

4. UNFPA: Preventing HIV infection. Global Youth Partners. Advocating for increased access by young people to information, education and services in the area of HIV prevention: http://www.unfpa.org/hiv/ gyp/index.htm.
5. Centers for Disease Control and Prevention. Young people at risk: HIV/AIDS among America's Youth, March 2002. Available at: http://www.cdc.gov/hiv/ pubs/facts/youth.htm. Accessed August 19, 2003.

6. UNAIDS and WHO. AIDS Epidemic Update. http://www.unaids.org/epi/2005/doc/EPIupdate2005 html_en/epi05 06 en.htm

7. Ke, C. ; Xun, L.; Ying, Y.: A Survey of AIDS related Knowledge, Attitude and Behavior among College Student $\mathrm{s}$ in 4 Cities of Fujian, China. $J$ Preventive Med, 2005, 11(1), 19-21.

8. Ailan, L.; Liming, L.: A Survey on STDs/ A IDS Knowledge, Perception and Sexual Behavior Among University Students in Beijing. $J$ Pub. Health of China, 1999, 15(6), 545-546.

9. Jin, H.; Honghong, W.; Ann, B. W.: The Relationship between Knowledge and Attitude about HIV/AIDS among University Students' in Changsha. Practical Preventive Med., 2003, 10(4), 4 454-458.

10. Lan, L. ; Lei, W. ; Qian, Z. : A Survey on the Knowledge, Attitude, Belief and Practice Related to AIDS among Hotel Attendants in Yichang City. $J$ Zhejiang Preventive Medicine, 2005, 17(4), 11 - 13.

11. Ping, Y.; Chuanwen, D.; Hualong, L.: Survey on the Knowledge of HIV/AIDS in Criminal Suspect. J. Tropical Medicine, 2006, 6(3), 328-330.

12. Hongbin, Z.: Investigation of HIV Knowledge among High Risk Groups in Maanshan City. J. Anhui $J$ Preventive Medicine, 2005, 11(1), 17-18.

13. Kathleen, J.; Sikkema, Michael; Brondino, J.; Andrson, Eileen S.: HIV Risk Behavior among Ethnically Diverse Adolescents Living in LowIncome Housing Developments. J. Adolescent Health, 2004, 35, 141-150.

14. Centers for Disease Control and Prevention. Youth Risk Behavior Surveillance-United States, 1997. MMWR Morb Mort Wkly Rep, 1998, 47, 1-91.

15. Mehmet, U.; Hakan, Y.: AIDS knowledge and educational needs of technical university students in Turkey. Patient Education and Counseling, 2003, 51, 163-167.

16. Jinglin, H.; Hongyuan, W.; Gang, C.: Investigation on sexual behavior of college students. J. for STDs and AIDS Prevention and Control, 1997, 3, 103-105.

17. Wu, Z.; Pingping, Y.: Research on knowledge, attitudes and practice about AIDS among university students in Fujian Province. J. Fujian Medical University, 2000, 34(2), 194-196.

18. Xinming, W.: Research on knowledge, attitudes and sexual belief among university students in Quanzhou City. Chinese J. Health Education, 2003, 19(12), 933.

19. Jichuan, C.: Investigation on knowledge, practice about STDs and AIDS among Ningde Normal School students. Chinese J. Health Education, 2003, 19(11), 853-854.

20. Everett, S. A. ; Warren, C. W. ; Santelli, J. S. : Use of birth control pills, condoms, and withdrawal among U.S. high school students, Adolescent Health, 2000, 27, 112-118. 